\title{
CROSSING THE BLOOD-BRAIN BARRIER BY NEUROINVASIVE PATHOGENS
}

\author{
Tkáčová, Z. ${ }^{1}$, Káňová, E. ${ }^{1}$, Jiménez-Munguía, I. ${ }^{1}$ \\ Čomor, L. ${ }^{1}$, Širochmanová, I. ${ }^{1}$, Bhide, K. ${ }^{1}$, Bhide, M. ${ }^{1,2}$ \\ 1Laboratory of Biomedical Microbiology and Immunology \\ University of Veterinary Medicine and Pharmacy, Kosice \\ ${ }^{2}$ Institute of Neuroimmunology, Slovak Academy of Sciences, Bratislava
}

Slovakia

zuzana.tkacova17@gmail.com

\section{ABSTRACT}

The penetration of the blood-brain barrier (BBB) and invasion of the central nervous system (CNS) are important steps for all neuroinvasive pathogens. All of the ways of pathogens passing through the $\mathrm{BBB}$ are still unclear. Among known pathways, pathogen traversal can occur paracellularly, transcellularly or using a "Trojan horse" mechanism. The first step of translocation across the $\mathrm{BBB}$ is the interactions of the pathogen's ligands with the receptors of the host brain cells. Lyme disease, the most common vector-borne disease in the temperate zones of Europe and North America, are caused by Borreliella species (former Borrelia burgdorferi sensu lato) that affects the peripheral and the CNS. In this review, we have presented various pathogen interactions with endothelial cells, which allow the disruption of the BBB so that the pathogens can pass across the BBB.

Key words: blood-brain barrier; Borreliella; paracellular and transcellular passage; "Trojan horse" mechanism

\section{INTRODUCTION}

Infections of the CNS, with associated high morbidity often cause serious permanent damage to the CNS [20]. Despite the availability of antimicrobial treatment, in the last two decades, an increase in the incidence of bacterial neuroinfections has been recorded. A large number of bacterial pathogenic species have the potential to infect the CNS. Nevertheless, it is not clear why a relatively small number of pathogens are responsible for infections of the CNS. Among various bacterial pathogens which cause infections of the CNS, Neisseria meningitidis, Borreliella, Streptococcus pneumoniae and Listeria monocytogenes are the most important ones in central Europe [30]. These pathogens are capable of crossing the BBB, where they invade the CNS, which further leads to damaged cells of the neurovascular unit (NVU). The neurovascular unit includes the brain microvascular endothelial cells (BMEC), glial cells, astrocytes and neurons [13] (Fig. 1). 


\section{Blood-brain barrier}

The $\mathrm{BBB}$ is a regulatory interface between the peripheral circulation and the CNS [30]. The BBB regulates the passage of blood-borne substances and cells into the brain and thus maintains the homeostasis of the neural microenvironment that is crucial for normal neuronal activity and function [1]. It is a specialized system which has a unique role in the protection of the brain from toxic substances in blood and filters harmful compounds from the brain back to the bloodstream. The BBB allows the passage of water, some gases, and lipid-soluble molecules by passive diffusion, as well as the selective transport of molecules such as glucose and amino acids [1]. The unique property of the $\mathrm{BBB}$ is primarily determined by the presence of endothelial junctional complexes made up of adherens junctions (AJs) and highly specialized tight junctions (TJs). Apart from the presence of specialized TJs, other unique properties of the $\mathrm{BBB}$ are the absence of fenestrae, reduced level of fluidphase endocytosis and asymmetrically localized enzymes [2]. An intact BBB prevents the transfer of macromolecules to the brain tissue. The penetration of substances into the brain, also avoids enzymatic barriers, which are composed of enzyme systems located in the walls of the cerebral blood vessels (e.g. aminopeptidase or monoaminooxidase).

\section{Cells of blood-brain barrier}

The BBB is formed by the brain microvascular endothelial cells (BMECs) that line the cerebral microvessels. The periendothelial structures of the BBB include pericytes (related to smooth muscle cells, surrounding the endothelium, reduced endothelial apoptosis and the stabilization of the endothelium), astrocytes (induce many BBB features and support the tissue of the CNS) and a basal membrane (Fig. 1). Astrocytes are glial cells that vastly outnumber the neurons in the brain. Astrocytes are involved in metabolic interactions with neurons, and also form close associations with endothelia and fibroblasts [52]. Less is known about the role of the pericytes in the BBB. The characteristic shape of astrocytes is a stellate appearance with long cytoplasmic processes. They are specialized cells within the capillary basement membrane, which help to maintain structural integrity and the function of the blood vessels [13]. The basal lamina of cerebral microvessels provides a scaffold upon which the endothelial and the glial compartments interact [2]. The BMECs interact dynamically with neighboring cells, astroglia, pericytes, and microglia that contribute to their unique characteristics. Despite the fact that astrocytes envelop more than $99 \%$ of the BBB endothelium, they are not directly involved in the physical properties of the BBB [23]. Interaction of astrocytes with the BMECs induces and modulates the development of the unique properties of the $\mathrm{BBB}$ which is the reduction in the adhesional and tight junctional gap areas [52].

Polarized cells have functions such as: the transport of ions and nutrients; secretion of protein products; and protection of the interior of the organism from pathogens. Cell polarity is observed in the functionally distinct portions of the plasma membrane known as the apical domain and the basolateral domain [35]. The apical domain contains anion channels, $\mathrm{H}^{+} / \mathrm{K}^{+-}$ATPase and transporters, whereas the lateral portion of the basolateral domain contains proteins involved in attachment to neighboring cells and cell-

BLOOD

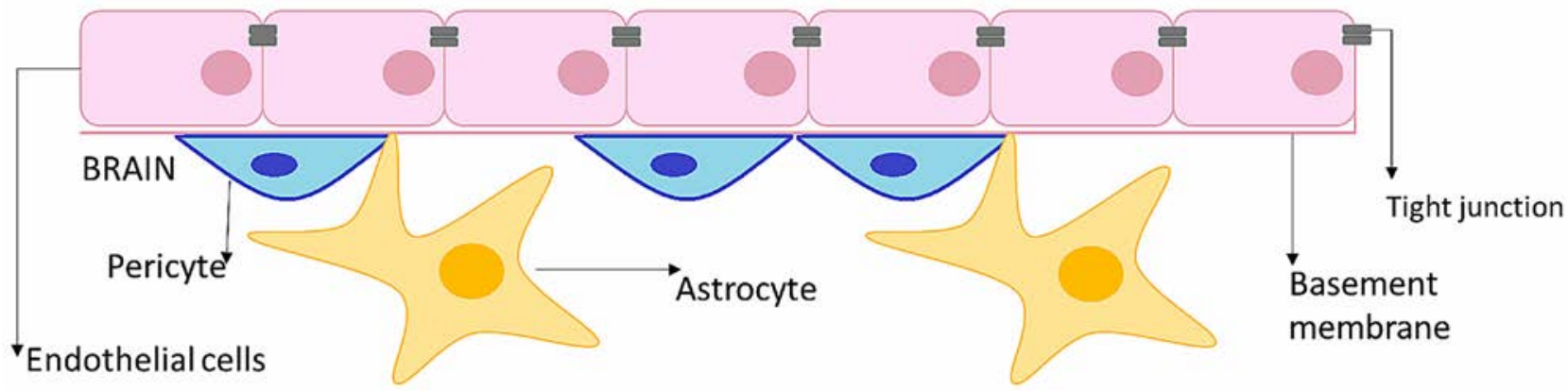

Fig. 1. Structure of the blood brain barrier

$\mathrm{BBB}$ consists mainly of brain microvascular endothelial cells (BMEC), pericytes, astrocytes and basement membrane. An original drawing 
cell communication. The basal portion of the basolateral domain contains the binding sites for constituents of the basal lamina, receptors for hormones and other signaling molecules that regulate the function of the cell [35]. The TJs, which are localized in the apical end of the basolateral membrane, play a key role in establishing endothelial polarity. The TJs of the cerebral microvasculature are composed of four integral membrane proteins - occludin [17], claudins [18], junctional adhesion molecules (JAM) [34] and the recently discovered endothelial cell-selective adhesion molecule [36] (Fig. 2).

\section{Traversal of the BBB by pathogens}

One of the basic steps in the invasion of a pathogen into the CNS is crossing through the BBB. Several pathogens are able to penetrate physiologically impermeable barriers such as the $\mathrm{BBB}$. There are two main types of passing through the $\mathrm{BBB}$, paracellular and transcellular [30] (Fig. 3). Crossing through the BBB is associated with protein-protein interactions between the pathogen and cells of the BBB. Some pathogens have developed an array of complex types of BBB disruptions. One of the most perfect mechanism of translocation, without mechanical damage to the $\mathrm{BBB}$ is the "Trojan horse" mechanism or mimicry of surface ligands on the host cells. Some neuroinvasive pathogens express the ligand of the surface receptors of the host proteases, which break down the extracellular matrix or components of the basal membrane.

1. Transcellular passage involves penetration of the patho- gens through the BMECs. This crossing is initiated by adherence of the pathogen to the ECs leading to the entry of the bacterium into the CNS across the BBB using pinocytosis or receptor-mediated mechanisms. Transcellular traversal of the BBB has been demonstrated for Escherichia coli [30], Group B Streptococcus [40], Listeria monocytogenes [21], Mycobacterium tuberculosis [27], Citrobacter freundii [3], Haemophilus influenzae [41], Streptococcus pneumoniae [45] and Candida albicans [28].

2. The paracellular route is defined as microbial infiltration between the cells. This traversal involves loosening of the TJs or disturbing the supporting components of TJs, i.e. basement membrane and glial cells [55]. The paracellular transmigration of the $\mathrm{BBB}$ has been suggested for the Trypanosoma [24] and Treponema pallidum [22].

Both routes have also been suggested for Cryptococcus neoformans [11, 12], Neisseria meningitidis $[38,10]$, and the Lyme disease pathogen Borrelia burgdorferi [9].

3. In the case of the "Trojan horse" mechanism, the first step is infection of leukocytes, primary lymphocytes, and/or mononuclear leukocytes by pathogens. Then these infected immune cells carry the pathogen through the BBB. This way of crossing is mainly used by bacteria that are able to survive in the host immune cells [30]. Passing the BBB by the "Trojan horse" mechanism has been suggested for bacteria such as Listeria monocytogenes and Mycobacterium tuberculosis [15].
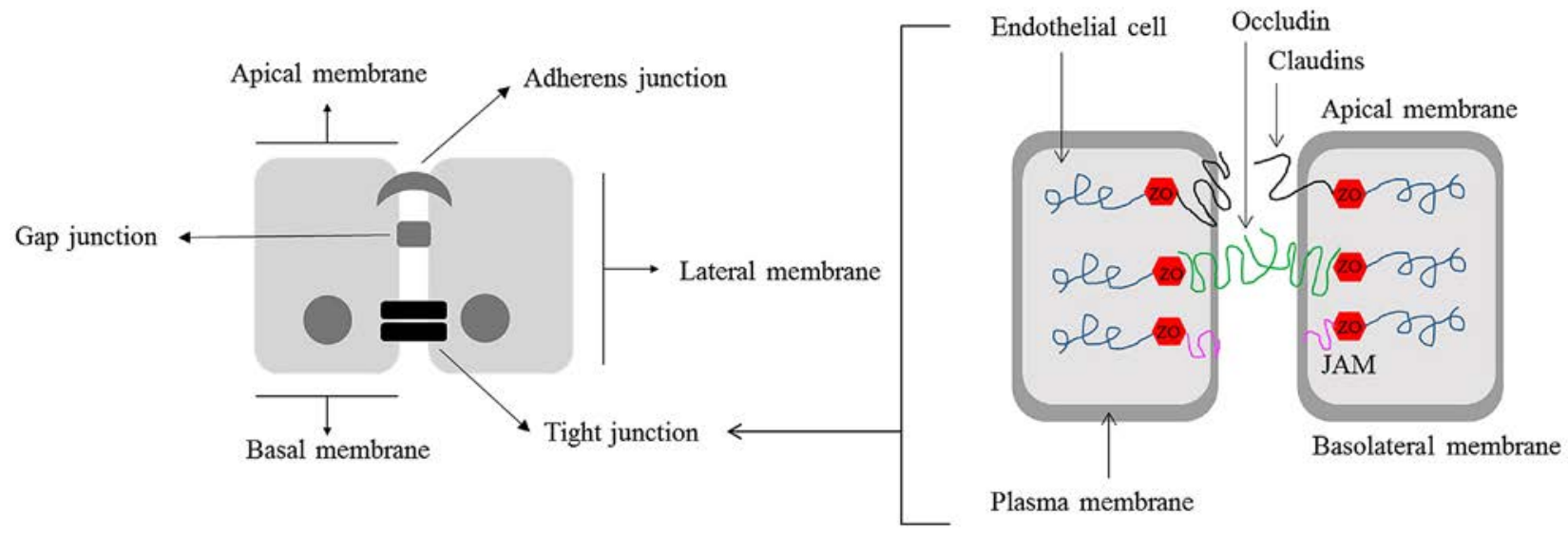

Fig. 2. Organization of intracellular junctions

BMEC attached to each other via adherens junctions, tight junctions and gap junctions. The TJs are composed of integral proteins: occludin, claudins, junctional adhesion molecules (JAM) and the recently discovered endothelial cell-selective adhesion molecule. Edited according to [35] 


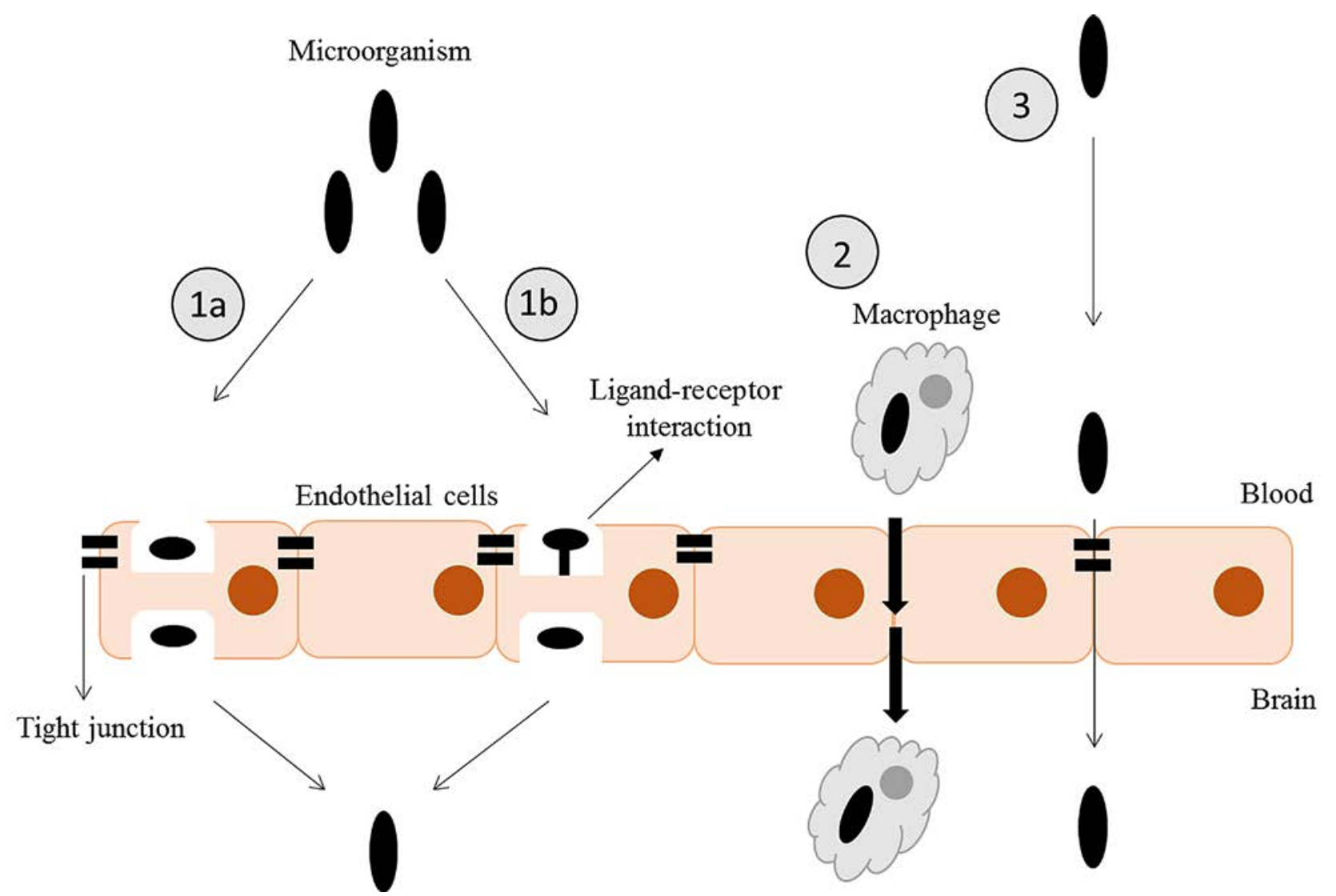

Fig. 3. Mechanisms of crossing through the BBB

1a) Transcellular penetration-pinocytosis (ligands are brought into endothelial cell, forming an invagination and they are released into brain); 1b) Transcellular penetration-ligand-receptor interaction (pathogen ligand interacts with host receptor and it allows the pathogen to cross the BBB); 2) The "Trojan horse" mechanism (Infected phagocytes to carry the pathogen through the BBB); 3 ) Paracellular penetration (Passage through the endothelial cells with or without disrupted tight and adherens junction). An original drawing

In recent years, the interest of researchers has been aimed at the cell signaling pathway, which is triggered after infection in the cells of the NVU. Neuroinvasive pathogens infect host cells through ligand-receptor interactions. Pathogens ligands interact with receptors, which are bound to the brain microvascular endothelial cells. These interactions are described in a variety of pathogens (Table 1).

\section{Transversal of the BBB by Borrelia}

Lyme disease is an infectious bacterial disease caused by the microaerophilic spirochete Borreliella species, which affects the peripheral and CNS. It is one of the most common tick-borne diseases in Europe and in North America [49]. Neurological complications, collectively termed neuroborreliosis, can occur in up to $15 \%$ of untreated patients. Typical symptoms of the damage of the CNS are headache, flu-like symptoms, fatigue, memory loss and depression. In the case of the infection of the peripheral nervous system, typical symptoms are the malfunction of the facial nerve and muscle weakness [49].

Several bacteria express their own proteases that digest the extracellular matrix in order to invade tissues, however, B. burgdorferi appear to utilize the fibrinolytic system of the host to disseminate [7]. B. burgdorferi does not produce any collagenase, elastase, hyaluronidase or plasminogen activators [31]. It is a well-known fact that Borreliella can bind plasminogen and promotes degradation of the ECM [7]. On the other hand, fibrinolytic system also initiates other proteases, including the matrix metalloproteinases (MMPs), which are predicted to be essential for borrelial invasion into the brain [16]. Plasminogen bound on the bacterial surface can be converted into plasmin by host activators [4]. Plasmin bound to the surface of the bacterial cell is stabilized and protected against inactivation by $\alpha 1$ and a2-antiplasmin [42]. Borreliella induces the expression and secretion of the urokinase-type plasminogen activa- 
Table 1. Protein-protein interactions during translocation of pathogen across the BBB

\begin{tabular}{|c|c|c|c|c|}
\hline Pathogen & $\begin{array}{l}\text { Predicted ways of } \\
\text { BBB penetration }\end{array}$ & Ligand (pathogen) & $\begin{array}{l}\text { Receptor } \\
\text { (host) }\end{array}$ & References \\
\hline E.coli & Transcellular & $\begin{array}{l}\text { CNF1 FimH } \\
\text { OmpA } \\
\text { IBEA }\end{array}$ & $\begin{array}{l}37 \text { LRP, } 67 \text { LRP CD48 Gp96 } \\
45-k \text { Da protein }\end{array}$ & $\begin{array}{c}{[14],[29]} \\
{[44]} \\
{[26]}\end{array}$ \\
\hline S. pneumoniae & Transcellular & Phosphorylcholin & Platelet-activating factor receptor & [45] \\
\hline L. monocytogenes & $\begin{array}{l}\text { Transcellular } \\
\text { "Trojan horse" } \\
\text { mechanism }\end{array}$ & $\begin{array}{l}\text { Internalin B } \\
\text { Vip ND }\end{array}$ & $\begin{array}{l}\mathrm{gC1q}-\mathrm{R} \text { (receptor for the globular head of the } \\
\text { complement component } \mathrm{C} 1 \mathrm{q}) \\
\text { Met receptor tyrosine kinase gp } 96 \\
\text { ND }\end{array}$ & $\begin{array}{c}{[21],[5],[47]} \\
{[6]} \\
{[15]}\end{array}$ \\
\hline Neisseria meningitidis & Transcellular & $\begin{array}{l}\text { Opc (outer membrane } \\
\text { protein) } \\
\text { Pili (Pil A and Pil B) }\end{array}$ & $\begin{array}{l}\text { Fibronektin (anchoring to the integrin- } a 5 \beta 1 \\
\text { receptor) } \\
\text { CD } 46\end{array}$ & $\begin{array}{l}{[56],[37]} \\
{[43]}\end{array}$ \\
\hline Group B Streptococci & Transcellular & $\begin{array}{l}\text { Glycosyltransferase } \\
\text { LTA } \\
\text { Lmb } \\
\text { FbsA } \\
\text { Pili (PilA and PilB) }\end{array}$ & $\begin{array}{l}\text { ND } \\
\text { Laminin } \\
\text { Fibrinogen } \\
\text { ND } \\
\text { ND }\end{array}$ & $\begin{array}{l}{[53]} \\
{[53]} \\
{[33]} \\
{[33]}\end{array}$ \\
\hline Treponema pallidum & Paracellular & ND & ND & [54] \\
\hline Borrelia burgdorferis. I. & $\begin{array}{l}\text { Transcellular } \\
\text { Paracellular }\end{array}$ & $\begin{array}{l}\text { ND } \\
\text { Vsp1 } \\
\text { OspA } \\
\text { 70-kDa PBP }\end{array}$ & $\begin{array}{l}\text { ND } \\
\text { Proteoglycans } \\
\text { Platelet integrins } \\
\text { Glycosaminoglycans } \\
\text { Glycosphingolipids } \\
\text { Plasmin(ogen) proteoglycans } \\
\text { Plasmin(ogen) }\end{array}$ & $\begin{array}{c}{[9]} \\
{[51]} \\
{[12]} \\
{[46]} \\
{[46]} \\
{[25]} \\
{[25]}\end{array}$ \\
\hline Mycobacterium tuberculosis & $\begin{array}{l}\text { "Trojan horse" } \\
\text { mechanism }\end{array}$ & $\begin{array}{l}\text { Upregulation of genes } \\
\text { Rv0980c } \\
\text { Rv0987c } \\
\text { Rv0989c } \\
\text { Rv1801 }\end{array}$ & $\begin{array}{l}\text { ND } \\
\text { ND } \\
\text { ND } \\
\text { ND }\end{array}$ & $\begin{array}{l}{[27]} \\
{[39]} \\
{[39]} \\
{[39]} \\
{[39]}\end{array}$ \\
\hline
\end{tabular}

N.D. - not detected (unknown)

tor ( $\mathrm{uPA}$ ) and the expression of the $\mathrm{uPA}$ receptor ( $\mathrm{uPAR}$; CD87) by a variety of cell types, including monocytes [8]. The protection of cell surface-bound plasmin from physiological inhibitors may allow the spirochete to traverse normal tissue barriers, to colonize organs and to propagate pathological processes within the affected tissues. Borreliella is able to activate and upregulate proinflammatory cells of human MMPs [19] and induce the release of MMP9 (gelatinase), and MMP1 (collagenase). These molecules are subsequently exploited for penetration through different host barrier, including the BBB [19].

Another alternative, which is used by Borreliella to translocate through the $\mathrm{BBB}$, is the exploitation of CD40. OspA of Borreliella binds CD40 expressed on brain endothelial cells of the host. This binding induces the expression of various types of integrins and the expression of matrix metalloproteinases (MMP3 and MMP9). Activation of CD40 in endothelial cells mediates downstream signaling that leads to the production of pro-inflammatory cytokines [35] and enhanced expression of ICAM-1, E-selectin, VCAM-1 with the consequent increase in cell binding, vascular endothelial growth factor (VEGF) and vascular permeability factor (VPF), and finally creates fenestrations $[50,48,32]$ that leads to a weakening of the barrier. OspA is undoubtedly a multifunctional protein that is absolutely necessary in the various stages of borrelial lifecycle and pathogenesis. It is also well known that Borreliella can bind plasminogen via OspA on their surface [12]. Plasminogen can be activated to plasmin $[12,8]$ leading to degradation of the extracellular matrix and translocation across the BBB. 


\section{CONCLUSIONS}

Passing through the BBB is an important step in the invasion of pathogens. This summary explains different ways of passages of pathogens across the BBB. The identification of pathogenic ligands and the understanding of ligand-receptor interactions helps us to unfold the basic principles of neuroinvasion and increases the probability of creating a suitable vaccine against such neuroinfections.

\section{ACKNOWLEDGEMENTS}

The study was supported by APVV-14-0218 and INFEKTZOON (Center of excellence for infections in animals and zoonoses, ITMS code: 26220120002, co-financed from the European structural funds) for the support of this study.

\section{REFERENCES}

1. Abbott, N. J., Ronnback, L., Hansson, E., 2006: Astrocyteendothelial interactions at the blood-brain barrier. Nat. Rev. Neurosci., 7, 41-53.

2. Archer, D. P., Ravussin, P. A., 1994: Role of blood-brain barrier in cerebral homeostasis. Ann. Fr. Anesth. Reanim., 13, $57-61$.

3. Badger, J.L., Stins, M.F., Kim, K.S., 1999: Citrobacter freundii invades and replicates in human brain microvascular endothelial cells. Infect. Immunol., 67, 4208-4215.

4. Berge, A., Sjobring, U., 1993: PAM, a novel plasminogenbinding protein from Streptococcus pyogenes. J. Biol. Chem., 268, 25417-25424.

5. Braun, L., Ohayon, H., Cossart, P., 1998: The InIB protein of Listeria monocytogenes is sufficient to promote entry into mammalian cells. Mol. Microbiol., 27, 1077-1087.

6. Cabanes, D., Sousa, S., Cebria, A., Lecuit, M., Garcia-del Portillo, F., Cossart, P., 2005: Gp96 is a receptor for a novel Listeria monocytogenes virulence factor, Vip, a surface protein. EMBO J., 24, 2827-2838.

7. Coleman, J.L., Roemer, E. J., Benach, J.L., 1999: Plasmincoated Borrelia burgdorferi degrades soluble and insoluble components of the mammalian extracellular matrix. Infect. Immunol., 67, 3929-3936.

8. Coleman, J.L., Gebbia, J.A., Benach, J.L., 2001: Borrelia burgdorferi and other bacterial products induce expression and release of the urokinase receptor (CD87). J. Immunol., $166,473-480$.

9. Comstock, L.E., Thomas, D.D., 1991: Characterization of Borrelia burgdorferi invasion of cultured endothelial cells. Microb. Pathog., 10, 137-148.

10. Coureuil, M., Mikaty, G., Miller, F., Bourdoulous, S., Duménil, G., Mège, R.M., et al., 2009: Meningococcal type IV pili recruit the polarity complex to cross the brain endothelium. Science, 325, 83-87.

11. Chang, Y.C., Stins, M.F., McCaffery, M.J., Miller, G.F., Pare, D. R., Dam, T., et al., 2004: Cryptococcal yeast cells invade the central nervous system via transcellular penetration of the blood-brain barrier. Infect. Immunol., 72, 4985-4995.

12. Charlier, C., Chretien, F., Baudrimont, M., Mordelet, E., Lortholary, O., Dromer, F., 2005: Capsule structure changes associated with Cryptococcus neoformans crossing of the blood-brain barrier. Am. J. Pathol., 166, 421-432 C.

13. Chauhan, V.S., Kluttz, J.M., Bost, K. L., Marriott, I., 2011: Prophylactic and therapeutic targeting of the neurokinin-1 receptor limits neuroinflammation in a murine model of pneumococcal meningitis. J. Immunol., 186, 7255-7263.

14. Chung, J. W., Hong, S. J., Kim, K. J., Goti, D., Stins, M.F., Shin, S., et al., 2003: 37-kDa laminin receptor precursor modulates cytotoxic necrotizing factor 1-mediated RhoA activation and bacterial uptake. J. Biol. Chem., 278, 16857-16862.

15. Drevets, D.A., Dillon, M. J., Schawang, J.S., Van Rooijen, N., Ehrchen, J., Sunderkotter, C., et al., 2004: The Ly-6Chigh monocyte subpopulation transports Listeria monocytogenes into the brain during systemic infection of mice. J. Immunol., $172,4418-4424$.

16. Fuchs, H., Wallich, R., Simon, M.M., Kramer, M.D., 1994: The outer surface protein A of the spirochete Borrelia burgdorferi is a plasmin(ogen) receptor. Proc. Natl. Acad. Sci. USA, 91, 12594-12598.

17. Furuse, M., Itoh, M., Hirase, T., Nagafuchi, A., Yonemura, S., Tsukita, S., 1994: Direct association of occludin with ZO-1 and its possible involvement in the localization of occludin at tight junctions. J. Cell Biol., 127, 1617-1626.

18. Furuse, M., Fujita, K., Hiiragi, T., Fujimoto, K., Tsukita, S., 1998: Claudin-1 and -2: novel integral membrane proteins localizing at tight junctions with no sequence similarity to occludin. J. Cell Biol., 141, 1539-1550.

19. Gebbia, J. A., Coleman, J. L., Benach, J. L., 2001: Borrelia spirochetes upregulate release and activation of matrix metalloproteinase gelatinase B (MMP-9) and collagenase 1 (MMP-1) in human cells. Infect. Immunol., 69, 456-462. 
20. Grab, D. J., Nikolskaia, O., Kim, Y.V., Lonsdale-Eccles, J. D., Ito, S., Hara, T., et al., 2004: African trypanosome interactions with an in vitro model of the human blood-brain barrier. J. Parasitol., 90, 970-979.

21. Greiffenberg, L., Goebel, W., Kim, K. S., Weiglein, I., Bubert, A., Engelbrecht, F., et al., 1998: Interaction of Listeria monocytogenes with human brain microvascular endothelial cells: InlB-dependent invasion, long-term intracellular growth, and spread from macrophages to endothelial cells. Infect. Immunol., 66, 5260-5267.

22. Haake, D. A., Lovett, M. A., 1994: Interjunctional invasion of endothelial cell monolayers. Methods Enzymol., 236, 447-463.

23. Hawkins, B. T., Davis, T.P., 2005: The blood-brain barrier/ neurovascular unit in health and disease. Pharmacol. Rev., 57, 173-185

24. Hoffman, O., Weber, R. J., 2009: Pathophysiology and treatment of bacterial meningitis. Advances in Neurological Disorders, 2, 1-7.

25. Hu, L.T., Pratt, S.D., Perides, G., Katz, L., Rogers, R.A., Klempner, M.S., 1997: Isolation, cloning, and expression of a 70-kilodalton plasminogen binding protein of Borrelia burgdorferi. Infect. Immunol., 65, 4989-4995.

26. Huang, S. H., Wass, C., Fu, Q., Prasadarao, N. V., Stins, M., Kim, K. S., 1995: Escherichia coli invasion of brain microvascular endothelial cells in vitro and in vivo: molecular cloning and characterization of invasion gene ibe10. Infect. Immunol., $63,4470-4475$.

27. Jain, S. K., Paul-Satyaseela, M., Lamichhane, G., Kim, K. S., Bishai, W.R., 2006: Mycobacterium tuberculosis invasion and traversal across an in vitro human blood-brain barrier as a pathogenic mechanism for central nervous system tuberculosis. J. Infect. Dis., 193, 1287-1295.

28. Jong, A.Y., Stins, M.F., Huang, S.H., Chen, S.H., Kim, K.S., 2001: Traversal of Candida albicans across human blood-brain barrier in vitro. Infect. Immunol., 69, 45364544.

29. Khan, N. A., Kim, Y., Shin, S., Kim, K. S., 2007: FimH-mediated Escherichia coli $\mathrm{K} 1$ invasion of human brain microvascular endothelial cells. Cell Microbiol., 9, 169-178.

30. Kim, K.S., 2008: Mechanisms of microbial traversal of the blood-brain barrier. Nat. Rev. Microbiol., 6, 625-634.

31. Klempner, M.S., Noring, R., Epstein, M.P., McCloud, B., Hu, R., Limentani, S. A., et al., 1995: Binding of human plasminogen and urokinase-type plasminogen activator to the Lyme disease spirochete, Borrelia burgdorferi. J. Infect. Dis., $171,1258-1265$.
32. Mach, F., Schonbeck, U., Bonnefoy, J. Y., Pober, J. S., Libby, P., 1997: Activation of monocyte/macrophage functions related to acute atheroma complication by ligation of CD40: induction of collagenase, stromelysin, and tissue factor. Circulation, 96, 396-9.

33. Maisey, H.C., Hensler, M., Nizet, V., Doran, K.S., 2007: Group B streptococcal pilus proteins contribute to adherence to and invasion of brain microvascular endothelial cells. J. Bacteriol., 189, 1464-1467.

34. Martin-Padura, I., Lostaglio, S., Schneemann, M., Williams, L., Romano, M., Fruscella, P., et al., 1998: Junctional adhesion molecule, a novel member of the immunoglobulin superfamily that distributes at intercellular junctions and modulates monocyte transmigration. J. Cell Biol., 142, 117-127.

35. Miyoshi, J., Takai, Y., 2005: Molecular perspective on tightjunction assembly and epithelial polarity. Advances Drug Delivery Reviews, 57, 815-855.

36. Nasdala, I., Wolburg-Buchholz, K., Wolburg, H., Kuhn, A., Ebnet, K., Brachtendorf, G., et al., 2002: A transmembrane tight junction protein selectively expressed on endothelial cells and platelets. J. Biol. Chem., 277, 16294-16303.

37. Nassif, X., Pujol, C., Morand, P., Eugene, E., 1999: Interactions of pathogenic Neisseria with host cells. Is it possible to assemble the puzzle? Mol. Microbiol., 32, 1124-1132.

38. Nassif, X., Bourdoulous, S., Eugene, E., Couraud, P.O., 2002: How do extracellular pathogens cross the blood-brain barrier? Trends Microbiol., 10, 227-232.

39. Nguyen, L., Pieters, J., 2005: The Trojan horse: survival tactics of pathogenic mycobacteria in macrophages. Trends Cell Biol., 15, 269-276.

40. Nizet, V., Kim, K.S., Stins, M., Jonas, M., Chi, E. Y., Nguyen, D., et al., 1997: Invasion of brain microvascular endothelial cells by group B streptococci. Infect. Immunol., 65, 5074-5081.

41. Orihuela, C. J., Mahdavi, J., Thornton, J., Mann, B., Wooldridge, K.G., Abouseada, N., et al., 2009: Laminin receptor initiates bacterial contact with the blood brain barrier in experimental meningitis models. J. Clin. Invest., 119, $1638-1646$.

42. Perides, G., Noring, R., Klempner, M.S., 1996: Inhibition of Borrelia burgdorferi-bound fibrinolytic enzymes by alpha2antiplasmin, PAI-1 and PAI-2. Biochem. Bioph. Res. Comm., $219,690-695$

43. Plant, L., Sundqvist, J., Zughaier, S., Lovkvist, L., Stephens, D.S, Jonsson, A.B., 2006: Lipooligosaccharide structure contributes to multiple steps in the virulence of Neisseria meningitidis. Infect. Immunol., 74, 1360-1367. 
44. Prasadarao, N. V., Srivastava, P. K., Rudrabhatla, R. S., Kim, K. S., Huang, S. H., Sukumaran, S. K., 2003: Cloning and expression of the Escherichia coli K1 outer membrane protein A receptor, a gp96 homologue. Infect. Immunol., 71, 16801688.

45. Ring, A., Weiser, J. N., Tuomanen, E. I., 1998: Pneumococcal trafficking across the blood-brain barrier. Molecular analysis of a novel bidirectional pathway. J. Clin. Invest., 102, 347-360.

46. Rupprecht, T. A., Koedel, U., Heimerl, C., Fingerle, V., Paul, R., Wilske, B., et al., 2006: Adhesion of Borrelia garinii to neuronal cells is mediated by the interaction of OspA with proteoglycans. J. Neuroimmunol., 175, 5-11.

47. Shen, Y., Naujokas, M., Park, M., Ireton, K., 2000: InIBdependent internalization of Listeria is mediated by the Met receptor tyrosine kinase. Cell, 103, 501-510.

48. Schonbeck, U., Mach, F., Sukhova, G. K., Murphy, C., Bonnefoy, J. Y., Fabunmi, R. P., Libby, P., 1997: Regulation of matrix metalloproteinase expression in human vascular smooth muscle cells by T lymphocytes: a role for CD40 signaling in plaque rupture? Circ. Res., 81, 448-54.

49. Steere, A. C., 2001: Lyme disease. N. Engl. J. Med., 345, 115125.

50. Sukhova, G. K., Schönbeck, U., Rabkin, E., Schoen, F. J., Poole, A. R., Billinghurst, R. C., Libby, P., 1999: Evidence for increased collagenolysis by interstitial collagenases- 1 and -3 in vulnerable human atheromatous plaques. Circulation, 99, $2503-2509$
51. Szczepanski, A., Furie, M. B., Benach, J. L., Lane, B. P., Fleit, H. B., 1990: Interaction between Borrelia burgdorferi and endothelium in vitro. J. Clin. Invest., 85, 1637-1647.

52. Tao-Cheng, J.H., Brightman, M.W., 1988: Development of membrane interactions between brain endothelial cells and astrocytes in vitro. Int. J. Dev. Neurosci., 6, 25-37.

53. Tenenbaum, T., Bloier, C., Adam, R., Reinscheid, D. J., Schroten, H., 2005: Adherence to and invasion of human brain microvascular endothelial cells are promoted by fibrinogen-binding protein FbsA of Streptococcus agalactiae. Infect. Immunol., 73, 4404-4409.

54. Thomas, D. D., Navab, M., Haake, D. A., Fogelman, A.M., Miller, J.N., Lovett, M.A., 1988: Treponema pallidum invades intercellular junctions of endothelial cell monolayers. Proc. Natl. Acad. Sci. USA, 85, 3608-3612.

55. Tuomanen, E., 1996: Entry of pathogens into the central nervous system. FEMS Microbiol. Rev., 18, 289-299.

56. Unkmeir, A., Latsch, K., Dietrich, G., Wintermeyer, E., Schinke, B., Schwender, S., 2002: Fibronectin mediates Opcdependent internalization of Neisseria meningitidis in human brain microvascular endothelial cells. Mol. Microbiol., 46, 933-946

Received, December 4, 2017

Accepted January 17, 2018 